\title{
EVALUASI PELAKSANAAN PROGRAM NASIONAL PEMBERDAYAAN USAHA MASYARAKAT MANDIRI KELAUTAN DAN PERIKANAN PADA USAHA PENGOLAHAN IKAN: Studi Kasus di Kota Banda Aceh Implementation of The National Program for Marine and Fisheries
Community Empowerment in The Fisheries Processing Business :
A Case Study in Banda Aceh City
}

\author{
'Yayan Hikmayani dan Riesti Triyanti \\ Balai Besar Penelitian Sosial Ekonomi Kelautan dan Perikanan \\ Gedung Balitbang KP I Lt. 4 \\ Jalan Pasir Putih Nomor 1 Ancol Timur, Jakarta Utara \\ Telp: (021) 64711583 Fax: 64700924 \\ *email: yayanhikmayani@yahoo.ca \\ Diterima 15 Maret 2015 - Disetujui 6 Juni 2015
}

\begin{abstract}
ABSTRAK
Program nasional pemberdayaan masyarakat mandiri kelautan dan perikanan pada sektor perikanan diwujudkan dalam bentuk pengembangan usaha mina pedesaan. Program penanggulangan kemiskinan melalui pemberdayaan masyarakat kelautan dan perikanan seringkali tidak tepat sasaran dan tidak memperhitungkan keberlanjutan program sehingga kemiskinan tidak berkurang bahkan semakin bertambah. Pengembangan Usaha Mina Perdesaan (PUMP) merupakan salah satu program Kementerian Kelautan dan Perikanan (KKP) ditujukan untuk menanggulangi kasus kemiskinan pada kelompok masyarakat tertentu. Tujuan penelitian ini adalah untuk menganalisis pelaksanaan Pengembangan Usaha Mina Perdesaan (PUMP) pada kelompok masyarakat pengolah dan pemasar hasil perikanan di Kota Banda Aceh, mengetahui respon masyarakat terhadap Pengembangan Usaha Mina Perdesaan Pengolahan dan Pemasaran Hasil Perikanan (PUMP P2HP), dan mengidentifikasi faktor-faktor yang mempengaruhi pelaksanaan program tersebut. Penelitian ini menggunakan pendekatan kualitatif dan pengumpulan data dilakukan melalui wawancara, observasi dan desk study. Pengambilan sampel ditentukan secara purposive dengan responden anggota kelompok pengolah dan pemasar hasil perikanan (POKLAHSAR) penerima program. Metode analisis data dilakukan secara deskriptif. Hasil penelitian menunjukkan bahwa pelaksanaan PUMP P2HP di setiap tahapannya secara normatif memang telah terlaksana dan terdapat kesesuaian antara ketentuan pedoman program dengan pelaksanaannya di masyarakat. Namun demikian, dalam hal pelaksanaannya sebagai sebuah program pemberdayaan, secara substansi masih jauh dari tujuan yang diharapkan. Hal ini didukung dengan analisis mengenai respon masyarakat terhadap pelaksanaan program, baik itu mengenai keberlanjutan program, keterlibatan dalam program, manfaat program, dan konflik selama pelaksanaan program. Faktor-faktor dominan yang dapat menghambat pelaksanaan program ini secara keseluruhan perlu dilakukan perubahan dan perbaikan. Faktor yang menjadi penghambat dan penunjang keberhasilan program yaitu kesesuaian lokasi, pemberian peralatan yang menunjang produksi, dan ketepatan calon penerima bantuan. Rekomendasi kebijakan untuk perbaikan pelaksanaan program bantuan langsung tunai (BLT) di masa depan yaitu (1) Penyederhanaan dalam prosedural kegiatan program, (2) Ketepatan pemilihan calon penerima, (3) Pelatihan dan pendampingan kepada para calon penerima maupun penerima bantuan, dan (4) Evaluasi terhadap program bantuan untuk pengembangan usaha dan kemandirian penerima bantuan secara berkelanjutan.
\end{abstract}

Kata Kunci: PUMP P2HP, pengolah dan pemasar, kesejahteraan masyarakat

\section{ABSTRACT}

Fish business development in the village level is considered as the natural program for marine and fisheries community empowerment. Poverty reduction programs through marine and fisheries community empowerment are does not effective and take into account the sustainability of the program so that poverty can not be reduced even increasing. National program of marine and fisheries in the fish processing business are considered one of the MMAF program intended to eliminate poverty in a certain society. The aims of this study was to analyze implementation of PUMP P2HP, particularly in Banda Aceh 
City, identify the public response to the PUMP P2HP, and identify factors that affect the implementation of the program. This research used a qualitative approach and data collection through interview, observation and desk study. Sample was determined using purposive sampling with respondents "kelompok pengolah dan pemasar" (POKLAHSAR) members participating in the program. The method of data analysis was carried out descriptively. Results show that the implementation of PUMP P2HP in each stage have indeed been implemented as in the guidelines on the implementation of programs in the community. However, in terms of its implementation as a policy of empowerment, it is still far from the expected goals. This is supported by an analysis of the public response to the implementation of the program, in relation to the sustainability of program, the participation in program, the benefits of program, and conflict occurred during implementation of the program. The dominant factors that can support and prevent the implementation of the program as a whole, that the implementation procedures should be be changed and improved. Inhibitory and supporting factor for success of the program were namely the suitability of the location, provision of equipment to support the production, and the accuracy of the prospective beneficiaries. Policy recommendations to improve implementation of the programs of direct cash assistance $(B L T)$ in the future were identified as follows: (1) simplification of the program process, (2) accuracy in selecting candidates (3) training and assistance to the recipients and beneficiaries, and (4) evaluation of the programs for business development and self-reliance of beneficiaries sustainable manner.

Keywords: PUMP P2HP, processor and marketers, community welfare

\section{PENDAHULUAN}

Penanggulangan kemiskinan dilakukan dengan berbagai pendekatan, mulai dari pendekatan pembangunan wilayah, pemberdayaan masyarakat, sampai pendekatan pemenuhan kebutuhan dasar. Pendekatan pemberdayaan saat ini merupakan cara yang paling popular untuk memecahkan masalah kemiskinan. Banyak upaya yang telah dilakukan untuk mengurangi kemiskinan di Indonesia. Pada umumnya upaya-upaya pemberdayaan masyarakat miskin yang dilakukan oleh pemerintah Indonesia berupa program atau proyek yang sifatnya top down dan tidak tepat sasaran. Selain itu terkesan hanya melaksanakan program atau proyek dan keberlanjutan program atau proyek tersebut kurang mendapat perhatian sehingga kemiskinan tidak berkurang bahkan semakin bertambah (Sahuri et al., 2012).

Sejak tahun 2001 hingga sekarang anggaran untuk program penanggulangan kemiskinan meningkat secara signifikan. Namun demikian alokasi anggaran yang besar tersebut tidak diikuti oleh penurunan jumlah penduduk miskin yang secara signifikan justru mengalami stagnasi, bahkan kenaikan (Katiman, 2012). Di sektor kelautan dan perikanan, penanggulangan kemiskinan dilakukan dengan pemberian bantuan untuk pembangunan fisik dan sebagai pengungkituntukmengembangkan usaha di bidang kelautan dan perikanan agar pelaku usaha dapat berkembang. Salah satu program Kementerian Kelautan dan Perikanan (KKP) yang ditujukan untuk pelaku usaha adalah
Program Nasional Pemberdayaan Masyarakat Mandiri Kelautan dan Perikanan (PNPM-MKP).

PNPM-MKP dilakukan melalui tiga komponen yaitu Pengembangan Usaha Mina Pedesaan (PUMP) Perikanan Tangkap, Perikanan Budidaya dan Pengolahan dan Pemasaran Hasil Perikanan, dan Pemberdayaan Usaha Garam Rakyat (PUGAR) serta Pengembangan Desa Pesisir Tangguh (PDPT). Pengembangan Usaha Mina Pedesaan Pengolah dan Pemasar Hasil Perikanan (PUMP-P2HP) merupakan upaya kegiatan yang dilaksanakan melalui fasilitasi bantuan pengembangan usaha bagi pengolah/ pemasar ikan dalam wadah Kelompok Usaha Kelautan dan Perikanan (KUKP). Pola dasar PUMP-P2HP dirancang untuk meningkatkan kemampuan POKLAHSAR yang terdiri dari kelompok pengolah dan pemasar hasil perikanan untuk mengembangkan usaha produktif dalam rangka mendukung peningkatan kemampuan dan pengembangan wirausaha bidang pengolahan dan pemasaran. Komponen utama pencapaian tujuan program PUMP-P2HP meliputi keberadaan Poklahsar, keberadaan (tenaga pendamping, tim koordinasi, pokja PUMP P2HP, tim pembina dan tim teknis), sosialisasi dan pelatihan, penyaluran dana BLM, pemantauan, evaluasi dan pelaporan. Keberhasilan program dari sisi output diindikasikan dengan tersalurkannya BLM kepada 1.500 kelompokPoklahsardi33Propinsidan terlaksananya fasilitasi penguatan kapasitas dan kelembagaan Poklahsar melalui sosialisasi, pelatihan dan pendampingan (DJP2HP, 2013). 
Pengembangan industri perikanan merupakan salah satu aktivitas pemberdayaan ekonomi rakyatyang menjadi prioritas pembangunan di Kota Banda Aceh. Namun pada kenyataannya pemerintah daerah maupun investor swasta masih belum sepenuhnya melirik industri pengolahan ikan antara lain: dendeng ikan, abon ikan, kerupuk ikan, ikan kayu/kemamah, dan ikan asin yang saat ini masih tergolong dalam skala usaha mikro dengan peralatan yang tradisional. Keengganan berinvestasi dikarenakan masih rendahnya peluang pasar sehingga tingkat perekonomian pengolah dan pemasar produk olahan perikanan masih rendah. Hal ini membutuhkan bantuan dari pemerintah pusat untuk mengembangkan usaha yang telah ada di Kota Banda Aceh melalui PUMP-P2HP.

Pelaksanaan kebijakan pada prinsipnya untuk mencapai tujuan suatu program (Nugroho, 2004 dalam Sahuri et al., 2012). Untuk pelaksanaankan kebijakan publik maka ada dua pilihan langkah yang ada, yaitu langsung dilaksanakan dalam bentuk program-program atau melalui formulasi kebijakan derivate atau turunan dari kebijakan publik tersebut. Pengertian kebijakan merujuk pada tiga hal yakni sudut pandang (point of view); rangkaian tindakan (series of actions) dan peraturan (regulations). Ketiga hal tersebut menjadi pedoman bagi para pengambil keputusan untuk menjalankan sebuah kebijakan. Kebijakan publik berarti "respon dari sebuah sistem terhadap demands/claims dan support yang mengalir dari lingkungannya". Oleh karena itu perlu dikaji bagaimana pelaksanaan suatu program, tingkat efektivitas suatu program dan bagaimana respon masyarakat terhadap suatu program yang ditetapkan oleh pemerintah. Program yang dimaksud adalah program nasional pemberdayaan masyarakat mandiri kelautan dan perikanan (PNPM-MKP).

Merujuk pada kondisi diatas, maka tujuan penulisan makalah ini adalah untuk menganalisis pelaksanaan PUMP P2HP di Kota Banda Aceh, mengetahui respon masyarakat terhadap PUMP-P2HP, mengidentifikasi faktor-faktor penunjang maupun penghambat keberhasilan PUMP-P2HP di Kota Banda Aceh dan mengidentifikasi permasalahan yang dihadapi saat pelaksanaan turunnya program dan kondisi saat ini. Informasi yang disampaikan, dapat dijadikan acuan kepada pemerintah pusat (KKP) untuk digunakan sebagai bahan evaluasi kebijakan pengembangan sistem dan desain program agar lebih mengena kepada masyarakat kelautan dan perikanan yaitu kemandirian dan pengurangan angka kemiskinan masyarakat pesisir.

\section{METODOLOGI}

\section{Kerangka Pemikiran Penelitian}

Program bantuan untuk pengolah dan pemasar hasil perikanan dikenal dengan PUMP P2HP telah dilaksanakan di beberapa wilayah sejak tahun 2011. Sasaran penerima program PUMP P2HP yaitu kelompok usaha pengolahan dan pemasaran produk perikanan dan kelautan. Tujuan PUMP-P2HP untuk meningkatkan kemampuan dan mengembangkan wirausaha bidang pengolahan dan pemasaran di pedesaan. Pola dasar PUMP-P2HP dirancang untuk meningkatkan kemampuan POKLAHSAR untuk mengembangkan usaha produktif dalam rangka mendukung peningkatan kemampuan dan pengembangan wirausaha bidang pengolahan dan pemasaran.

Komponen utama kegiatan PUMP-P2HP adalah:

\section{a. Keberadaan POKLAHSAR}

b. Keberadaan tenaga pendamping, Tim Koordinasi, Pokja PUMP P2HP, Tim Pembina dan Tim Teknis

c. Sosialisasi dan pelatihan

d. Penyaluran dana BLM

e. Pemantauan, evaluasi dan pelaporan.

Indikator keberhasilan output dari PUMP P2HP adalah: 1) Tersalurkannya BLM kepada 1.500 Kelompok Usaha Pengolah dan Pemasar (POKLAHSAR) di 33 Propinsi; dan 2) Terlaksananya fasilitasi penguatan kapasitas dan kelembagaan POKLAHSAR melalui sosialisasi, pelatihan dan pendampingan (DJP2HP, 2013). Indikator keberhasilan output yang ditentukan tersebut tentunya masih belum mencerminkan bagaimana pelaksanaan dari kegiatan yang dilakukan sehingga tidak memberikan informasi rinci tentang kegagalan dan keberhasilan dalam proses pelaksanaan.

Pengukuran kinerja program PUMP P2HP menurut indikator yang lain perlu dilakukan. Hal ini untuk memberikan lebih banyak informasi tentang keberhasilan maupun kekurangan dari program yang telah dilakukan. Dalam penelitian ini akan dilakukan evaluasi pelaksanaan program baik dari mulai perencanaan sampai pelaksanaan. 
Berdasarkan hal tersebut maka kegiatan evaluasi akan dilakukan beberapa identifikasi sebagai berikut: 1) Identifikasi kinerja input-prosesoutput penerima bantuan terhadap pelaksanaan PUMP-P2HP, 2) Identifikasi respon penerima bantuan terhadap PUMP-P2HP, dan 3) Identifikasi faktor-faktor penunjang maupun penghambat keberhasilan PUMP-P2HP di Kota Banda Aceh, 4) Identifikasi permasalahan yang dihadapi.

Pertama, dilakukan identifikasi kinerja input, output dan proses terdiri dari tahap persiapan penentuan calon penerima, penyiapan dan verifikasi dokumen yang dilakukan oleh POKJA dalam hal ini pendamping dengan POKLAHSAR yang mengajukan proposal bantuan PUMP-P2HP. Penentuan kinerja dimulai dari proses penyaluran bantuan, pelaporan dan pengendalian sampai pembinaan. Penentuan kinerja output dilihat dengan mengevaluasi kesesuian pelaksanaan. Kedua, dilakukan identifikasi kinerja penerima bantuan terhadap pelaksanaan PUMP-P2HP serta respon penerima bantuan. Ketiga, Identifikasi terhadap faktor penghambat maupun penunjang keberhasilan PUMP-P2HP serta permasalahan yang dihadapi baik pada saat pelaksanan kegiatan penurunan bantuan sampai kondisi saat ini.

Acuan untuk penilaian keberhasilan program untuk kegiatan pertama digunakan alat ukur yang ada pada pedoman teknis pemberian bantuan PUMP-P2HP yang dikeluarkan oleh
Direktorat Jenderal Pengolahan dan Pemasaran Hasil Perikanan (DJ-P2HP). Penilaian untuk kegiatan kedua dan ketiga akan dilakukan dengan menganalisis data primer hasil lapangan.

Hasil analisa tersebut akan dijadikan dasar untuk merumuskan keberlanjutan program PNPM Mandiri KP. Apabila hasil penelitian menunjukkan tingkat keberhasilan program PNPM adalah baik, maka diasumsikan dapat membantu pencapaian target pembangunan KP. Apabila hasil penelitian menunjukkan hasil yang negatif, maka perlu evaluasi terhadap pelaksanaan program PNPM selanjutnya. Kerangka pemikiran yang mencakup konsep pendekatan dan kerangka analisis yang akan dilakukan dalam penelitian ini digambarkan secara visual pada Gambar 1.

\section{Lokasi dan Waktu Penelitian}

Penelitian dilakukan di Kota Banda Aceh pada bulan Agustus 2014 dengan lokasi penelitian terfokus pada 4 (empat) Kecamatan (Kuta Alam, Kuta Raja, Syiah Kuala, Meuraxa) sebagai lokasi penerima bantuan PUMP-P2HP Tahun 2011 sampai dengan 2013.

\section{Data dan Teknik Pengumpulan Data}

Penelitian merupakan penelitian kualitatif dengan metode penelitian survey, yaitu penelitian dengan mengambil sampel dari suatu populasi dan menggunakan kuesioner sebagai alat pengumpul

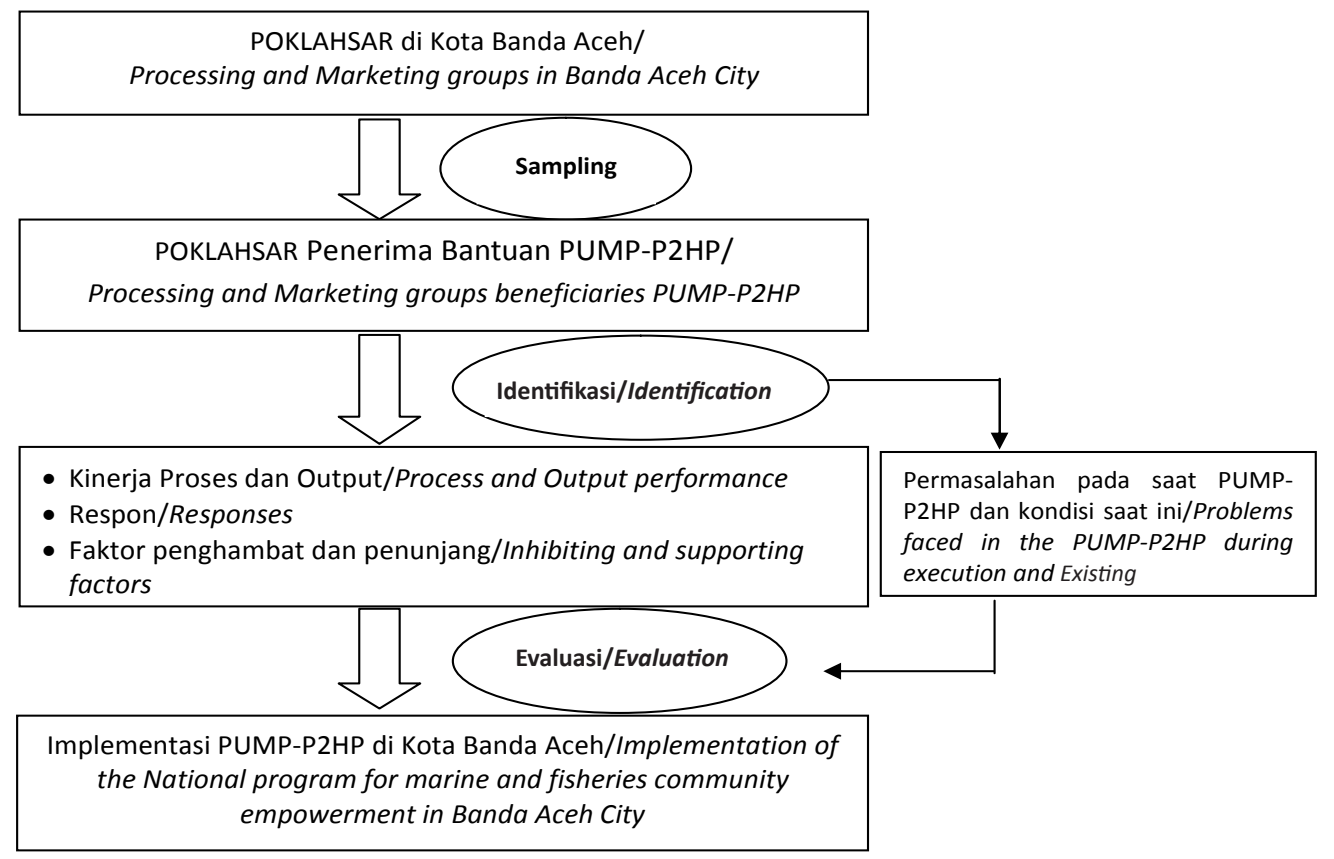

Gambar 1. Kerangka Pemikiran Penelitian

Figure 1. Research Framework 
data yang utama. Moeloeng (2006) menyatakan bahwa penelitian kualitatif bermaksud untuk memahami fenomena tentang apa yang dialami oleh subjek penelitian dengan cara holistik dan dengan cara deskripsi. Selanjutnya Sugiyono (2010) metode penelitian kualitatif dipilih karena permasalahan belum jelas, holistik, komplek, dinamis dan penuh makna.

Populasi dalam penelitian ini adalah seluruh Poklahsar yang ada di Kota Banda Aceh dan tersebar di 4 kecamatan. Poklahsar terdiri dari ketua, sekretaris, bendahara dan anggota. Ketua merupakan pemilik usaha sedangkan sekretaris, bendahara dan anggota merupakan tenaga kerjanya. Jumlah anggota dalam Poklahsar masing-masing sebanyak 10 (sepuluh) orang. Teknik pengambilan sampel yang digunakan dalam penelitian ini adalah pendekatan multi stage random sampling.

Pada tahap pertama pengambilan sampel dilakukan dengan menggunakan metode purposive sampling kemudian dilanjutkan dengan simple random sampling. Metode purposive sampling yaitu penentuan responden yang dilakukan secara sengaja dengan menggunakan kriteria tertentu dalam penelitian ini sesuai dengan subyek evaluasi yaitu masyarakat penerima program bantuan PUMP P2HP. Pada tahap kedua yang menjadi target dalam pengambilan sampel adalah semua kelompok penerima bantuan PUMP P2HP yang mempunyai probabilitas atau kesempatan yang sama untuk dipilih menjadi sampel (responden). Sampel diambil secara acak tanpa memperhatikan tingkatan yang ada dalam populasi berdasarkan Tabel Isaac \& Michael dengan tingkat kepercayaan sebesar $5 \%$. Syarat metode simple random sampling diantaranya harus tersedia sampling frame walaupun keterangan homogenitas unit elementer, pembagian dalam kelompok tidak perlu diketahui terlebih dahulu. Untuk masyarakat penerima bantuan PUMP-P2HP, yang dijadikan populasi adalah masyarakat penerima bantuan tahun 2011-2013 (Tabel 1).
Data terdiri dari data primer dan sekunder. Data primer diperoleh melalui wawancara dengan menggunakan kuesioner terstruktur yang meliputi data tentang perencanaan, pelaksanaan serta output program. Selain wawancara kepada responden contoh tersebut, juga akan dilakukan pula wawancara mendalam (in-depth) menggunakan pedoman pertanyaan terhadap beberapa orang informan kunci, pelaku pengembangan usaha terkait program dan para pengambil kebijakan kelautan dan perikanan daerah yang berhubungan dengan pelaksanaan program PUMP P2HP. Teknik pengumpulan data sekunder yang digunakan oleh penulis adalah library research (penelitian keperpustakaan) dengan sumber data laporan pelaksanaan PUMP-P2HP Tahun 2011, 2012 dan 2013 dari Dinas Kelautan dan Perikanan Kota Banda Aceh, Kota Banda Aceh dalam Angka Tahun 2012 dari Badan Pusat Statistik Kota Banda Aceh, dan hasil penelitian terdahulu (skripsi, thesis, jurnal).

\section{Teknik Analisis Data}

Untuk menjawab tujuan pertama yaitu kinerja program PUMP P2HP dari sisi input, proses dan output pada peserta program akan dilakukan analisis secara deskriptif kualitatif dan kuantitatif menggunakan statistik sederhana atas respon peserta program. Berdasarkan pedoman teknis pelaksanaan PUMP P2HP, indikator kinerjanya, secara umum dapat disajikan dalam Tabel 2.

Penilaian kinerja mencakup kinerja input, proses, output dengan menggunakan skor seberapa besar persentase tingkat ketepatan atas program PUMP P2HP, dan faktor-faktor yang mempengaruhinya. Analisis kuantitatif untuk menentukan skor atas ketepatan dilakukan melalui analisis statistik dengan menggunakan skala likert (Sebagai salah satu skala sikap). Untuk pengembangan teknik analisis penelitian yang akan mengarah pada pengukuran sikap, terutama untuk keperluan konfirmasi atau cross check pernyataan informan.

Tabel 1. Jumlah Populasi dan Sampel Penelitian, 2014.

Table 1. Total Population and Sample Research, 2014.

\begin{tabular}{ccc}
\hline Tahun/Year & $\begin{array}{c}\text { Jumlah Populasi (orang)/ } \\
\text { Total Population (person) }\end{array}$ & $\begin{array}{c}\text { Jumlah Sampel/Responden (orang)/ } \\
\text { Total Sample/Respondents (person) }\end{array}$ \\
\hline 2011 & 80 & 4 \\
2012 & 120 & 6 \\
2013 & 50 & 3 \\
\hline Total & $\mathbf{2 5 0}$ & $\mathbf{1 3}$ \\
\hline
\end{tabular}

Sumber: Direktorat Jenderal Pengolahan dan Pemasaran Hasil Perikanan, 2013/

Source: Directorat General of Fisheries Product Processing and Marketing, 2013 
Tabel 2. Indikator Penilaian Kinerja PUMP P2HP.

Table 2. Indicators of Performance Assessment of PUMP P2HP.

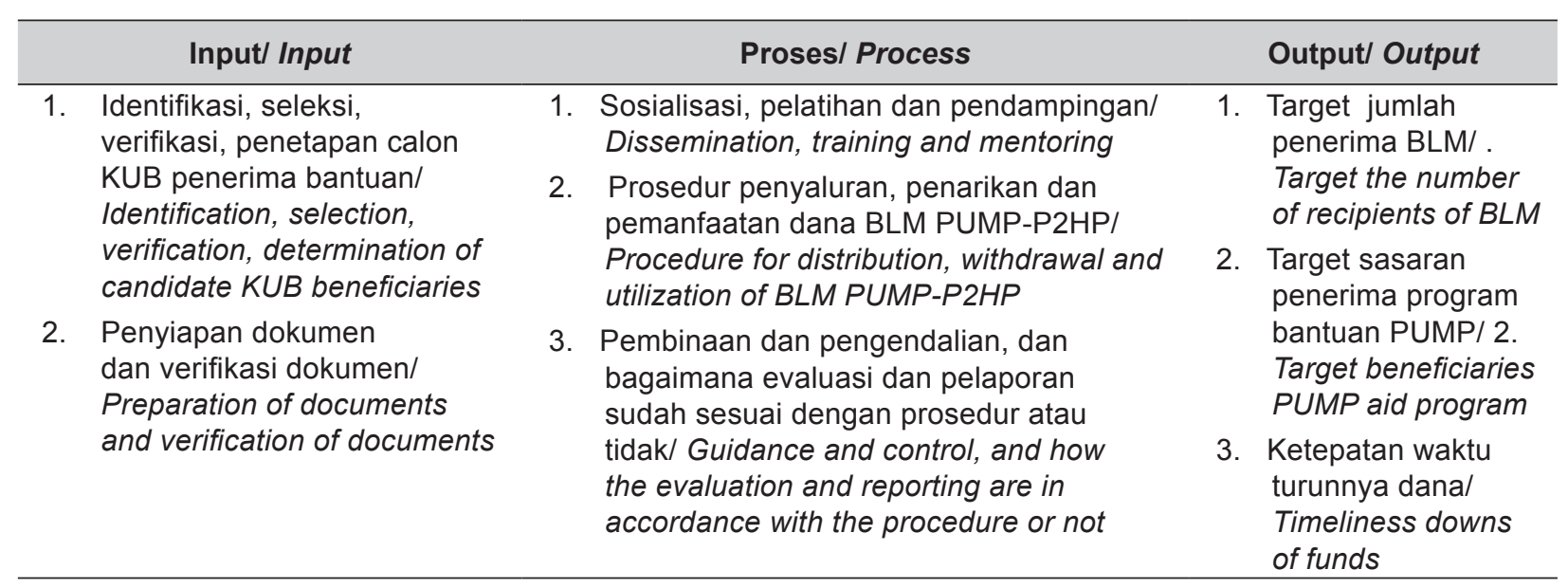

Sumber: Data sekunder diolah (2014)/ Source: Secondary Data is Processed (2014)

Jawaban dari setiap item variabel dari skala likert mempunyai gradasi (jenjang atau tingkat), dari sangat positif sampai sangat negatif yang dapat berupa kata. Untuk keperluan analisis kuantitatif, maka setiap pernyataan atau pertanyaan dapat menggunakan tiga gradasi atau jenjang.

Tabel 3...Indikator Penilaian Variabel untuk Mengukur Tingkat Keberhasilan Program PUMP P2HP di Lokasi Penelitian, 2014.

Table 3. Assessment Indicators for Measuring Success Rate Variable PUMPProgram P2HP on Location Research, 2014.

\begin{tabular}{llc}
\hline No. & Indikator/ Indicators & Nilai/ Value \\
\hline 1. & Baik/Good & $(3)$ \\
2. & Sedang/ Medium & $(2)$ \\
3. & Rendah/ Low & $(1)$ \\
\hline
\end{tabular}

Adapun hasil penjumlahan skor setiap jawaban akan dibagi dengan jumlah responden sehingga diperoleh rata-rata skor setiap pertanyaan, dengan menggunakan rumus:

$$
S k o r=\frac{\lfloor(F 1 \times B N 1)+(F 2 \times B N 2)+(F 3 \times B N 3)\rfloor}{N}
$$

Dengan keterangan :

$$
\mathrm{F} 1, \mathrm{~F} 2, \mathrm{~F} 3=\text { Frekuensi/ Frequency }
$$

BN1, BN2, BN3 = Bobot Nilai/ Weight Value

$\mathrm{N}=$ Jumlah Responden/ Number of Respondent

Skala ordinal yang dimiliki kemudian diubah menjadi data interval, dengan cara mencari rata-rata skor setiap item (indikator terukur) dari variabel independen (tahapan sesuai pedoman teknis PUMP P2HP) dan dependen (angka mutlak maupun persentase kinerja input-proses-output), dalam klasifikasi:

a. Baik : Apabila skor rata-rata dari indikator $(2-<3)$ atau $60 \%<100 \%$

b. Sedang: Apabila skor rata-rata dari indikator $(1-2)$ atau $20 \%-<60 \%$

c. Rendah: Apabila skor rata-rata dari indicator $(<1)$ atau $<20 \%$.

Untuk menjawab tujuan kedua yaitu memperoleh respon atas pelaksanaan program dilakukan dengan menggunakan likert type scale analysis. Disamping itu, penafsiran serta pembahasan dari hasil analisis yang dilakukan secara keseluruhan/komprehensif juga digunakan untuk memperkuat analisis. Penyusunan formulasi perumusan kebijakan tersebut juga akan diperkaya dengan hasil tinjauan kebijakan pemerintah terhadap program PUMP P2HP yang dikaji.

Untuk menjawab tujuan ketiga terkait identifikasi dan evaluasi permasalahan yang dihadapi dalam pelaksanaan program digunakan analisis deskripsi potensi dan permasalahan dalam pelaksanaan PUMP P2HP dengan metode Tree Diagram dan Expected Value. Terutama dalam upaya membangun minabisnis perdesaan dan pemberdayaan kelompok. Sementara itu, untuk menganalisis permasalahan yang dihadapi sebelum dan sesudah pelaksanaan program PUMP P2HP akan dilihat berbagai permasalahan/ kendala secara berjenjang dalam struktur pelaksanaannya dan juga sesuai tahapan yaitu mulai dari tingkat perencanaan program, 
pelaksanaan hingga tingkat pelaksanaan program. Analisis akan dilakukan analisis secara deskriptif kualitatif. Menurut Miles dan Huberman (2007) analisis data kualitatif adalah suatu proses analisis yang terdiri dari tiga alur kegiatan yang terjadi secara bersamaam yatiu reduksi data, penyajian data dan penarikan kesimpulan atau verifikasi.

\section{HASIL DAN PEMBAHASAN}

\section{A. Pelaksanaan Pelaksanaan PUMP-P2HP}

Pelaksanaan program PUMP-P2HP dilihat berdasarkan kinerja stakeholder terhadap pelaksanaan program bantuan yang terdiri dari kinerja input, proses, dan output. Secara garis besar implemetasi pelaksanaan program bantuan PUMP P2HP telah dilakukan secara baik. Kinerja pelaksanaan secara umum dapat dilihat pada Gambar 2.
Kinerja input mulai dari identifikasi, penyiapan dokumen dan verifikasi dokumen telah dilaksanakan dengan cukup baik sampai baik, sementara untuk kinerja proses masih ada pelaksanaan yang masih rendah yaitu untuk kegiatan evaluasi dan pelaporan. Dari hasil wawancara yang dilakukan pelaksanaan monitoring dan evaluasi tidak dilakukan secara rutin leh petugas, serta tidak dilakukan evaluasi untuk menilai kinerja dan keberhasilan program. Menurut Yulianti (2012) faktor penghambat keberhasilan program berbantuan disebabkan karena pihak pemberi program belum memiliki dokumen pelaksanaan monitoring dan evaluasi dan pelaksanaan kegiatan monitoring dan evaluasi tidak jelas.

Implementasi program harus senantiasa dievaluasi untuk melihat sejauh mana program tersebut telah berhasil mencapai tujuan program yang telah ditetapkan sebelumnya.

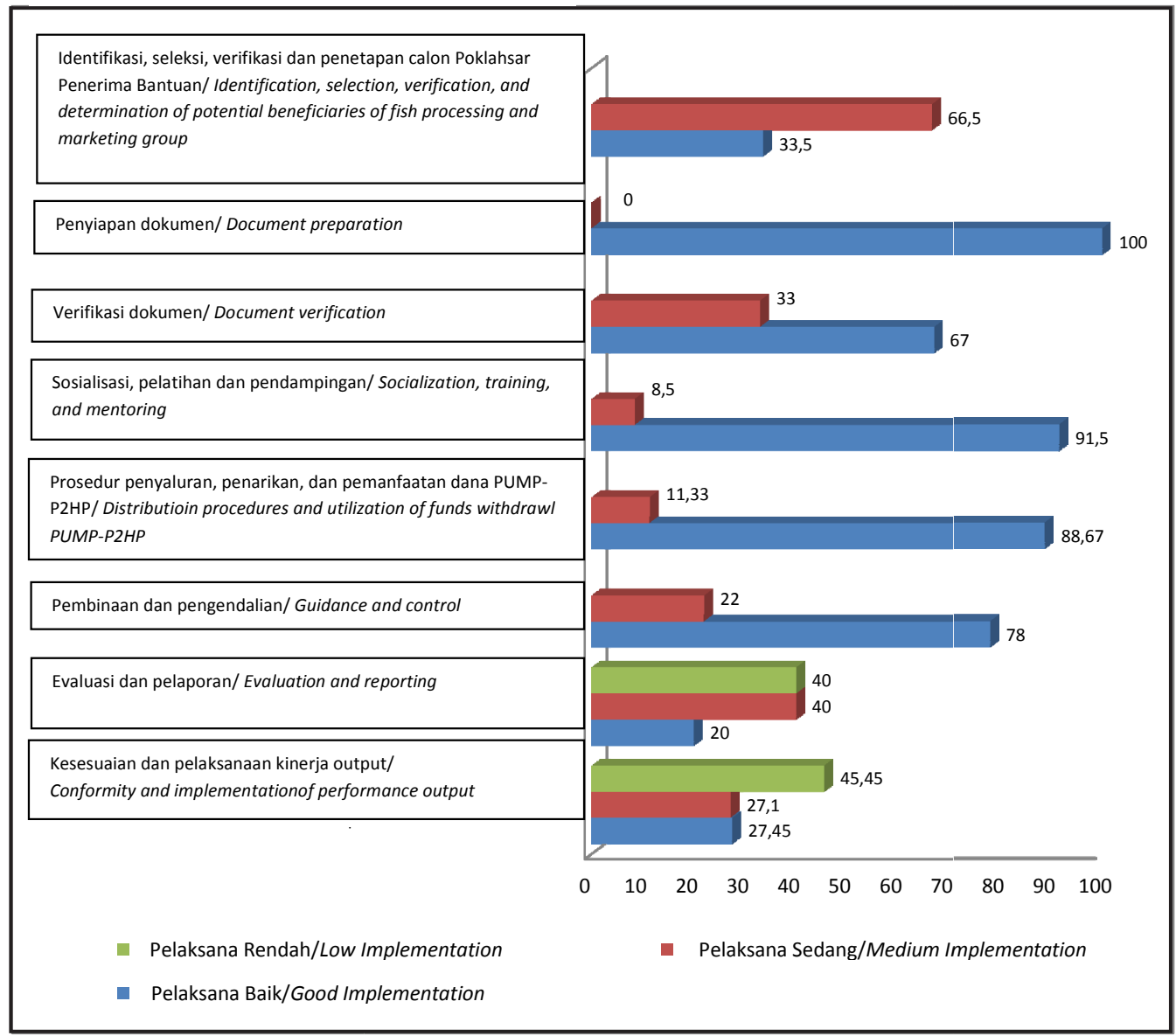

Gambar 2. Kinerja Stakeholder Terhadap Pelaksanaan PUMP-P2HP di Kota Banda Aceh Tahun 2011- 2013.

Figure 2. Implementation of Stakeholder Performance Against PUMP-P2HP in Banda Aceh in 2011- 2013.

Sumber : Data Primer Diolah, 2014/ Source : Primary Data Processed, 2014 
Secara lebih rinci, hasil evaluasi kinerja setiap tahapan pelaksanaan program PUMP P2HP di jelaskan seperti di bawah.

\section{Evaluasi Kinerja Input}

Kinerja input dinilai berdasarkan kesesuaian tahapan yang harus dilakukan mulai dari pengusulan program bantuan. Tahapan dalam kinerja input terdiri dari tahapan identifikasi, seleksi, verifikasi, dan penetapan calon Kelompok Usaha Bersama (KUB) penerima bantuan, penyiapan dokumen dan verifikasi dokumen.

Hasil evaluasi kinerja input dalam pelaksanaan PUMP-P2HP secara umum sudah sesuai dengan yang dipersyaratkan dan tercantum dalam pedoman teknis pelaksanaan program. Namun demikian, dalam pelaksanaannya masih ada beberapa hal yang dianggap masih belum sesuai dengan yang dilakukan.

Hasil analisis data menunjukkan bahwa untuk tahap pelaksanaan kinerja input tergolong dalam kategori sedang $(66,5 \%)$. Ketentuan pelaksanaan tersebut seperti tercantum pada Surat Keputusan Dirjen P2HP No. 037/KEP-DJP2HP/2013 mengenai Pedoman Teknis Pengembangan Usaha Mina Pedesaan Pengolahan dan Pemasaran Hasil Perikanan Tahun 2013 yang didalamnya dijelaskan kriteria umum maupun khusus penerima BLM PUMP-P2HP.

Beberapa hal yang masih dianggap kurang memuaskan yaitu dalam pelaksanaan Identifikasi, Seleksi, Verifikasi dan Penetapan Calon KUB Penerima Bantuan. Kegiatan yang tidak sesuai dengan petunjuk teknis yaitu:

a. Kelompok pengolah pemasar (Poklahsar) yang terpilih sebagai calon penerima tidak seluruhnya berusaha pengolahan ikan atau pemasar ikan, namun ada satu yang ternyata tidak melakukan usaha pengolahan. Selain itu pemilihan calon penerima bantuan PUMPP2HP masih dianggap tidak transparan sehingga tidak jarang menyebabkan timbulnya kecurigaan dari sesama pengolah. Penyiapan untuk pengusulan penerima bantuan dikerjakan sepenuhnya oleh tenaga pendamping. Penerima bantuan yaitu pemilik unit pengolahan dan anggota kelompok merupakan tenaga kerja dari usaha tersebut. Seluruh aset dan bantuan permodalan yang sifatnya natura sepenuhnya diterima oleh pemilik usaha pengolahan. Keikutsertaaan anggota dalam penentuan alokasi serta pembelanjaan juga tidak dilibatkan

b. Rata-rata Poklahsar yang terpilih tidak memiliki anggota baru yang merupakan tambahan tenaga kerja baru (minimal sebanyak 20\% dari jumlah anggota) sesuai ketentuan dari Petunjuk Teknis. Kepengurusan kelompok tidak aktif, hanya dilakukan oleh Ketua nya saja karena sebagai pemilik usaha pengolahan, sedangkan anggotanya adalah tenaga kerjanya.

c. Khusus untuk PUMP P2HP di Kota Aceh, tidak tersedia tenaga pendamping yang khusus menangani proses turunnya bantuan sehingga kegiatan verifikasi agak terhambat, tenaga pendamping yang ada dipindah tugas ke daerah lain.

\section{b. Evaluasi Kinerja Proses}

Kinerja proses merupakan tahapan yang terkait dengan proses turunnya bantuan PUMP P2HP. Tahapan yang harus dilalui terdiri dari bagaimana sosialisasi, pelatihan dan pendampingan; prosedur penyaluran, penarikan dan pemanfaatan dana BLM PUMP-P2HP; pembinaan dan pengendalian; dan evaluasi dan pelaporan.

Berdasarkan hasil analisis data dan hasil verifikasi di lokasi penelitian dari 4 (empat) tahapan dalam kinerja proses maka evaluasi dan pelaporan pelaksanaannya tergolong rendah $(40 \%)$, sedang $(40 \%)$ dan baik (20\%). Hal ini disebabkan bahwa kewajiban dalam penyampaian laporan perkembangan pelaksanaan bantuan PUMP-P2HP hanya dilakukan pada akhir tahun untuk pemenuhan laporan ke DJP2HP saja. Sementara laporan tentang perkembangan usaha, pemanfaatan sarana dan prasarana yang dibelanjakan dari dana BLM dan permasalahan usaha secara bulanan dan semesteran tidak dilakukan. Kegiatan evaluasi pelaksanaan di awal dan di akhir turunnya bantuan juga tidak dilakukan. Hal ini terlihat bahwa bantuan hanya diberikan pada Poklahsar tanpa dilihat keberlanjutan usahanya setelah mendapat bantuan tersebut.

\section{Evaluasi Kinerja Output}

Kinerja output merupakan tolok ukur kinerja berdasarkan produk (barang dan jasa) yang dihasilkan dari program atau kegiatan sesuai 
dengan masukan yang digunakan. Kinerja output dinilai berdasarkan 3 (tiga) keberhasilan yaitu penerima bantuan, fasilitasi penguatan kapasitas dan kelembagaan pada kelompok / penerima program, keberlanjutan usaha/keberhasilan usaha penerima bantuan.

Dari hasil analisis menunjukkan bahwa kinerja output tergolong dalam kategori rendah yaitu pada tahap evaluasi dan pelaporan $(40 \%)$ serta kesesuaian dan pelaksanaan kinerja output $(45,45 \%)$. Rendahnya kinerja output tersebut dipengaruhi oleh beberapa faktor yaitu ketepatan penyaluran bantuan dengan musim produksi, tidak adanya fasilitasi penguatan kapasitas dan kelembagaan pada kelompok/penerima program dan masih banyaknya bantuan yang digunakan untuk kegiatan non usaha seperti pemenuhan kebutuhan konsumsi rumah tangga, biaya sekolah anak, dan peralatan yang diberikan dijual kembali. Penyebab rendahnya kinerja output karena monitoring dan kontrol dari DJ-P2HP maupun POKJA tidak dilakukan, lamanya proses turunnya bantuan mulai dari pengurusan dokumen awal, dan tidak adanya tindakan tegas dari DJ-P2HP terhadap penyalahgunaan bantuan.

\section{B. Respon Penerima Bantuan Terhadap Pela ksanaan PUMP-P2HP}

Respon penerima bantuan terhadap pelaksanaan program PUMP-P2HP di Kota Banda Aceh dilihat berdasarkan dua hal yaitu reson terhadap pelaksanaan dan respon terhadap keberlanjutan program.

\section{Respon Terhadap Pelaksanaan Program}

Penilaian respon terhadap pelaksanaan program diidentifikasi mulai dari tahap penyusunan pedoman teknis sampai pelaporan. Secara umum, respon masyarakat penerima program PUMP P2HP di Kota Banda Aceh dari hasil penelitian digolongkan kedalam kategori baik (setuju), sedang (kurang setuju) dan rendah (tidak setuju) seperti dapat dilihat dari Gambar 3.

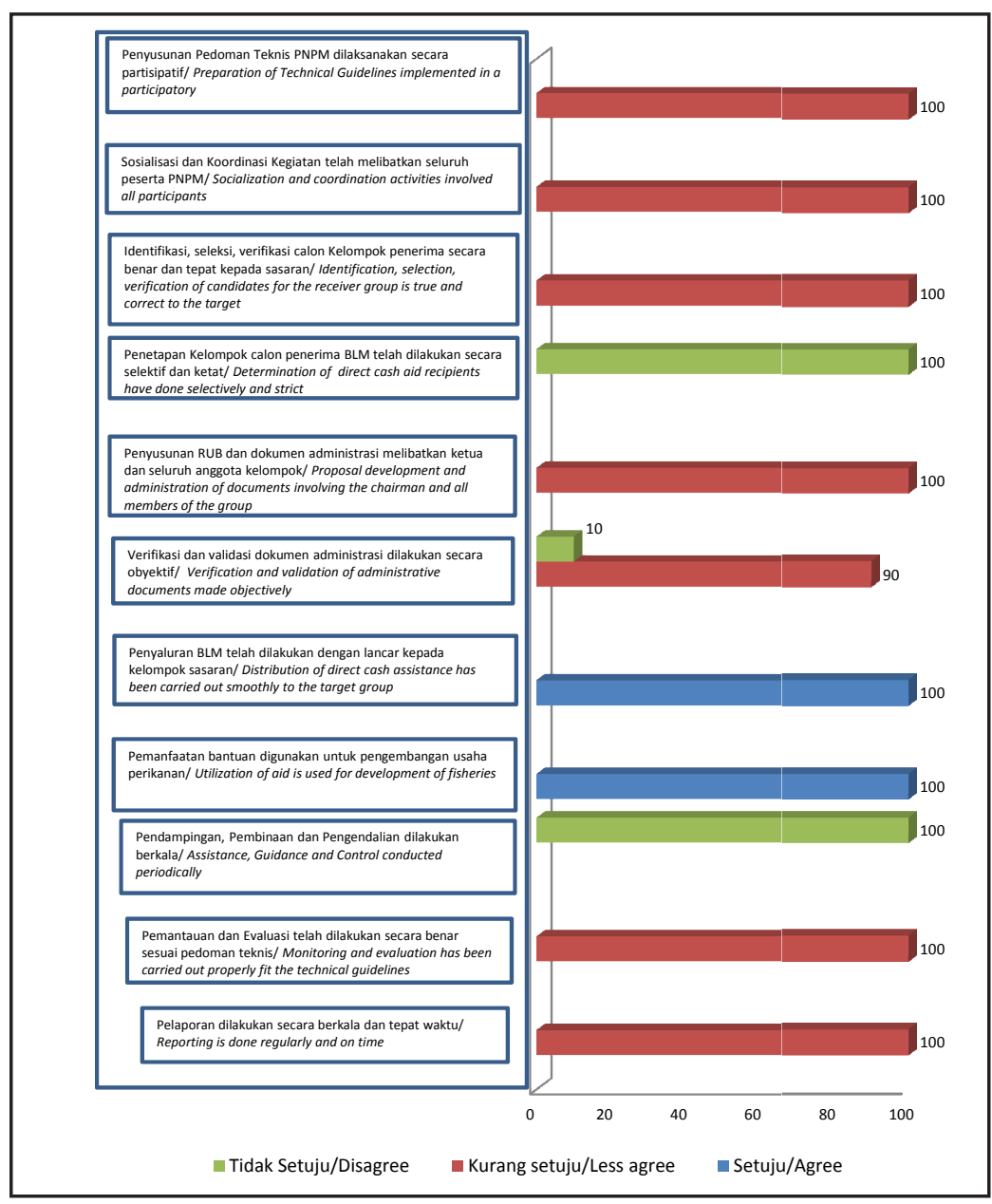

Gambar 3. Respon Kelompok Penerima Bantuan PUMP-P2HP di Kota Banda Aceh Tahun 2011-2013. Figure 3. Response of PUMP-P2HP Beneficiaries Group in Banda Aceh in 2011-2013.

Sumber: Data Primer Diolah, 2014/ Source: Primary Data Processed, 2014 
Berdasarkan Gambar 3 menunjukkan bahwa respon terhadap adanya bantuan PUMP-P2HP didominasi oleh kategori sedang (kurang setuju) masing-masing $100 \%$. Tahapan pelaksanaan PUMP-P2HP yang kurang dipahami oleh penerima bantuan seperti pedoman teknis PNPM, sosialisasi dan koordinasi kegiatan, identifikasi, seleksi, verifikasi calon kelompok penerima, penyusunan RUB dan dokumen administrasi, verifikasi dan validasi dokumen administrasi, pemantauan dan evaluasi, serta pelaporan secara berkala.

Berdasarkan Gambar 3 menunjukkan bahwa respon terhadap adanya bantuan PUMP-P2HP didominasi oleh kategori sedang/kurang setuju masing-masing $100 \%$. Tahapan pelaksanaan PUMP-P2HP yang kurang dipahami oleh penerima bantuan seperti pedoman teknis PNPM, sosialisasi dan koordinasi kegiatan, identifikasi, seleksi, verifikasi calon kelompok penerima, penyusunan RUB dan dokumen administrasi, verifikasi dan validasi dokumen administrasi, pemantauan dan evaluasi, serta pelaporan secara berkala.

Tahapan yang masih dianggap kurang diantaranya kurang adanya pelibatan seluruh penerima bantuan PUMP-P2HP. Pelibatan penerima bantuan dalam setiap tahapan kegiatan hanya diwakili oleh pengurus kelompok saja (ketua/sekretaris), sehingga anggota kelompok kurang paham terhadap tahapan turunnya bantuan PUMP-P2HP. Dari hasil survey diketahui bahwa keberadaan anggota kelompok seringkali bukan sebagai pengolah yang mempunyai usaha sendiri namun hanya sebagai tenaga kerja saja dari kegiatan usaha pengolahan.

Respon terhadap pelaksanaan bantuan PUMP-P2HP dengan kategori baik (setuju) terdiri dari penyaluran bantuan kepada kelompok sasaran. Penyaluran bantuan dianggap telah dilakukan dengan lancar dan pemanfaatan bantuan digunakan untuk mendukung usaha pengolahan. Seluruh responden menyatakan setuju dan melakukannya sesuai dengan usulan yang dimasukkan di Rencana Usaha Bersama (RUB), meskipun beberapa alat yang diberikan tidak sesuai dengan yang dibutuhkan. Di Kota Banda Aceh yang sebagian besar merupakan pengolah ikan kayu/kemamah, freezer dan wadah perebusan sangat bermanfaat bagi usaha tersebut. Karakteristik ikan yang cepat busuk memerlukan tempat untuk menyimpan ikan agar awet baik sebelum perebusan maupun setelah penjemuran. Beberapa alat bantuan yang kurang dimanfaatkan oleh penerima bantuan adalah gerobak bakso, karena sepinya konsumen yang membeli bakso ikan maka gerobak tersebut tidak digunakan.

Respon masyarakat terhadap pelaksanaan PUMP-P2HP dengan kategori rendah (tidak setuju) terjadi pada tahap penetapan kelompok calon penerima BLM yang belum dilakukan secara selektif dan ketat. Berdasarkan hasil observasi di Desa Lampulo, Kecamatan Kuta Alam beberapa penerima bantuan tergolong dalam kelompok utama yang telah memiliki pengalaman usaha lebih dari 10 tahun namun masih kurang untuk akses pasar dan kelangsungan bahan baku. Kelompok dalam kategori ini sebaiknya, selain memperoleh bantuan teknologi pengolahan dan alat pendingin, juga perlu pendampingan, pembinaan dan pengendalian mengenai informasi pasar dari Dinas Kelautan dan Perikanan Kota Banda Aceh dan penyuluh perikanan. Tahap verifikasi dan dan validasi dokumen administrasi tidak dilakukan secara objektif khususnya pada kelompok aspirasi. Kelompok ini merupakan kelompok titipan yang harus diberikan bantuan PUMP-P2HP. Tahap pendampingan, pembinaan, dan pengendalian tidak dilakukan secara berkala, tahap ini hanya dilakukan hanya diawal dan akhir proses turunnya bantuan saja, penyebabnya adalah keterbatasan pendamping dan cakupan wilayah pendampingan yang sangat luas.

\section{Respon Penerima Program Terhadap Keberlanjutan Program}

Penilaian respon terhadap keberlanjutan program berguna untuk menilai perlu tidaknya program dilanjutkan. Aspek yang dinilai untuk melihat respon terhadap keberlanjutan yaitu perubahan jam kerja, peningkatan pendapatan, peralihanjenis pekerjaan, manfaat yang ditimbulkan, perbaikan fasilitas perikanan dan peluang konflik yang bisa terjadi. Menurut Patton yang dikutip oleh Shaw et al. (2006:6), yaitu pengumpulan informasi secara sistematis tentang kegiatankegiatan, karakteristik dan outcomes untuk menilai program, peningkatan efektivitas program dan atau menginfromasikan keputusan tentang program mendatang. Sedangkan menurut Dunn (2003:608) sesuatu efektif bila mencapai tujuan tertentu.

Secara umum bantuan PUMP-P2HP yang diberikan kepada POKLAHSAR penerima BLM telah menunjukkan keberlanjutan. Program yang telah dilakukan telah memberikan dampak positif berupa perbaikan atau penambahan alat-alat pengolah 
sehingga bisa meningkatkan produksi secara kontinyu, produk yang dihasilkan lebih hygienis, tahan lama dan berdampak pada peningkatan pendapatan. Manfaat lainnya yaitu terciptanya lapangan kerja baru karena adanya peningkatan produksi dan juga terserapnya tenaga-tenaga kerja baru. Hal ini sejalan dengan hasil penelitian yang dilakukan oleh Asih et al. (2008), pemberian bantuan permodalan atau kredit mengakibatkan peningkatan alokasi curahan waktu kerja rumah tangga dalam kegiatan perikanan. Kondisi ini mengakibatkan peningkatan produksi berdampak pada peningkatan pendapatan dan kemampuan untuk mengakumulasi modal yang diterima bagi perkembangan usaha di masa yang akan datang, yang ditunjukkan dengan peningkatan tabungan (Paturohman, 2007). Tabungan meningkat jika pertambahan pendapatan makin besar. Artinya makin tinggi tingkat pendapan, maka makin besar kemampuan menabungnya. Jika pendapatan meningkat $1 \%$ maka tabungan meningkat lebih besar dari 1\%. Hal ini sejalan dengan pendapat yang disampaikan oleh Samuelson dan Nordhaus (1986) bahwa orang yang sangat miskin tidak akan dapat menabung sama sekali karena konsumsinya lebih banyak daripada pendapatannya. Hal ini disebabkan mereka belum bisa mengatur pendapatan rumahtangganya untuk kebutuhan ekonomi (peningkatan kapasitas usaha) dan kebutuhan sosialnya.

\section{Faktor Penunjang dan Penghambat Pelaksanaan PUMP-P2HP}

Dari hasil penelitian menunjukkan bahwa faktor yang berpengaruh terhadap keberhasilan program PUMP-P2HP di Kota Banda Aceh yaitu ketepatan pemilihan lokasi dan calon Poklahsar, ketepatan waktu penyaluran, kesesuaian peralatan yang diberikan, jumlah alat olah dan skala produksi serta keterampilan usaha, umur calon penerima bantuan, tingkat pendidikan dasar dan lamanya pengalaman usaha yang dimiliki.

Sementara faktor penunjang keberhasilan pelaksanaan PUMP-P2HP yaitu jumlah alat olah, skala produksi dan status usaha, kesesuaian jenis dan sarana usaha dengan peralatan yang diberikan, ketepatan pemilihan calon penerima bantuan dan ketepatan lokasi pemilihan untuk PUMP-P2HP. Secara lebih rinci penjelasan untuk masing-masing faktor tersebut dapat dilihat pada Gambar 4.

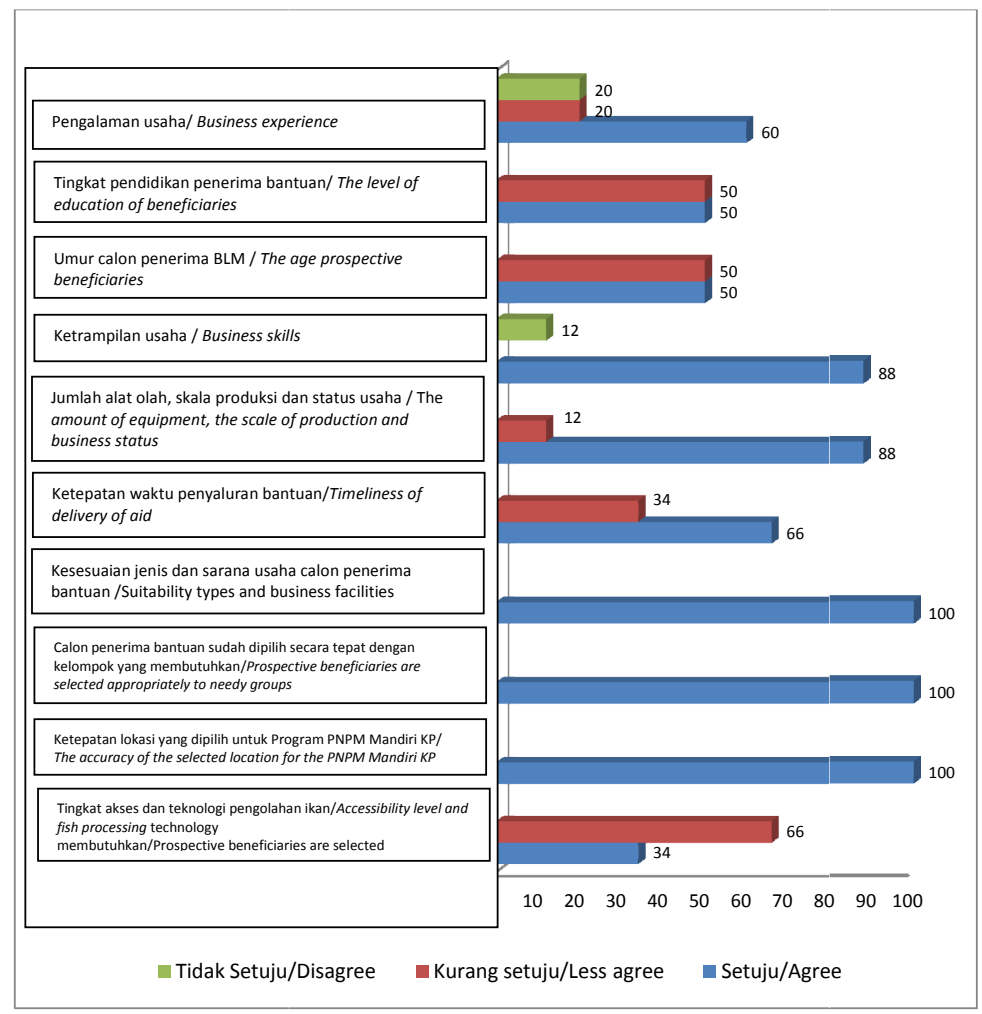

Gambar 4. Faktor Penunjang dan Penghambat Keberhasilan PUMP-P2HP di Kota Banda Aceh Tahun 2011-2013.

Figure 4. Supporting and Inhibiting Factors for Success of the PUMP-P2HP in Banda Aceh in 2011-2013. 
Dari hasil penelitian juga menunjukkan bahwa faktor penunjang keberhasilan program dapat memberikan dampak pada peningkatan kegiatan usahanya. Faktor internal dari penerima program yang dirasakan oleh beberapa pengolah/ pemasar sangat penting untuk menunjang keberhasilan PUMP-P2HP yaitu pengalaman usaha $(20 \%)$ dan keterampilan usaha pelaku usaha (12\%).

Bagi pelaku usaha yang sudah memiliki pengalaman dan keterampilan lebih lama rata-rata sudah mempunyai akses terhadap pasar yang menampung produk olahan mereka dan sudah dirasakan keuntungannya. Menurut Muniza (2010) menyatakan bahwa pengalaman/lama berusaha pada bidang usaha sejenis merupakan kekuatan utama bagi pengusaha.

Sementara itu terdapat juga faktor penghambat yang mempengaruhi keberhasilan pelaksanaan PUMP-P2HP yaitu tingkat akses dan teknologi pengolahan ikan yang masih rendah. Faktor ini dirasa penting oleh penerima program yang sebagian besar masih menggunakan teknologi tradisional. Ikan kayu/kemamah yang diolah secara tradisional menghasilkan produk olahan yang masih belum dikatakan baik karena warna ikan coklat/ gelap dan seringkali kotor akibat terkontaminasi dengan abu saat perebusan maupun penjemuran. Menurut Nikijuluw (2001), memfungsikan penyuluh perikanan dalam menyediakan akses teknologi bagi masyarakat belum sepenuhnya berjalan dengan baik.

\section{Permasalahan yang dihadapi oleh Penerima PUMP-P2HP}

Permasalahan yang dihadapi oleh penerima PUMP P2HP di Kota Banda Aceh yang dievaluasi dibedakan menjadi permasalahan yang dihadapi selama pelaksanaan program dan permasalahan saat survey dilakukan.

Permasalahan yang terjadi pada saat pelaksanaan program digolongkan menjadi 5 (lima) jenis yaitu rendahnya peluang pasar, tingginya biaya investasi, kelangsungan bahan baku, kurangnya pengetahuan tentang proyek dan kurangnya pendampingan. Dari hasil penelitian, menunjukkan bahwa permasalahan yang banyak ditemui selama pelaksanaan program yaitu kurangnya pengetahuan tentang skema proyek secara utuh dan kurangnya pendampingan. Hasil penelitian sejalan dengan hasil evaluasi program PNPM KP di Ternate menyatakan bahwa pendampingan masih dirasakan kurang intensif sehingga pengawasan dan pendampingan harus lebih intens terhadap kelompok masyarakat penerima bantuan program (Djalal dan Lasabuda. 2012). Sementara permasalahan yang dihadapi pada saat survey dilakukan yaitu kelangkaan bahan baku dan rendahnya peluang pasar. Menurut Nikijuluw (2001), membuka akses pasar adalah untuk mengembangkan usaha karena bila tidak ada pasar maka usaha sangat terhambat perkembangannya

Kelangkaan bahan baku dirasakan semakin terasa dari tahun ke tahun. Bahan baku ikan kayu terdiri dari ikan cakalang, tongkol dan tuna kecil. Kelangkaan bahan baku disebabkan karena musim yang tidak dapat diprediksi dan berpengaruh terhadap ketersediaan bahan baku yang dibutuhkan oleh pengolah ikan kayu. Berdasarkan data KKP tahun 2013, secara nasional produksi ikan cakalang tahun $2012-2013$ turun $11,18 \%$ dan ikan tongkol turun $2,9 \%$. Walaupun sumberdaya pelagis kecil di perairan WPP-RI 572 tersebut di estimasi menduduki peringkat pertama, diikuti oleh pelagis besar peringkat ketiga (DJP2HP, 2011). Namun demikian dari data statistik tahun 2013, produksi ikan pelagis (Tongkol dan Cakalang) mengalami penurunan hasil tangkapan dari tahu 2005 sampai 2012.

Masih lemahnya akses terhadap pasar diluar Aceh merupakan permasalahan umum yang dihadapi oleh pengolah. Pasar ikan kayu berlokasi di sekitar pasar Kota dengan pedagang ikan kayu yang ada dipasar. Pembayaran jarang dilakukan secara tunai melainkan dengan tempo satu minggu bahkan sampai satu bulan. Sebenarnya potensi pasar untuk Kota Medan cukup besar, namun tidak dapat dilakukan oleh pengolah langsung karena keterbatasan akses. Beberapa pengolah ada yang melakukan penjualan ikan kayu ke Medan dan sering juga mereka tertipu dengan tidak dibayar karena pedagangnya menghilang. Ketergantungan pengolah terhadap pedagang ikan di pasar cukup tinggi. Peran pemerintah sangat diperlukan untu dapat mengatasi permasalahan akses pasar tersebut. Hasil penelitian Djalal dan Lasabuda (2011) terhadap pelaksanaan PUMP P2HP di Kota Ternate Tahun Anggaran 2009 menyimpulkan bahwa pemerintah perlu mendorong peran serta lembaga permodalan dan pemasaran guna menunjang usaha masyarakat pesisir dan pengawasan dan pendampingan harus lebih intens terhadap kelompok masyarakat penerima bantuan program. 
Tabel 4. Permasalahan yang dihadapi Pelaku Usaha Pengolahan Ikan di Kota Banda Aceh, 2014. Table 4.The ProblemsFaced on Fish Processing and Marketing in Banda Aceh City, 2014.

\begin{tabular}{ll}
\multicolumn{1}{c}{$\begin{array}{c}\text { Permasalahan yang dihadapi pada PUMP-P2HPI } \\
\text { Problems faced in the PUMP-P2HP }\end{array}$} \\
\hline \multicolumn{1}{c}{ Selama pelaksanaan/ During execution } & Kondisi saat ini/ Present condition \\
\hline $\begin{array}{l}\text { 1. Rendahnya peluang pasar/Low market } \\
\text { opportunities }\end{array}$ & $\begin{array}{l}\text { 1. Kelangsungan bahan baku/ Continuity of } \\
\text { raw materials }\end{array}$ \\
$\begin{array}{l}\text { 2.. Tingginya biaya investasi/ High investment } \\
\text { costs }\end{array}$ & $\begin{array}{l}\text { 2. Rendahnya peluang pasar/ Low market } \\
\text { opportunities }\end{array}$ \\
$\begin{array}{ll}\text { 3. Kelangsungan bahan baku/Continuity of } \\
\text { raw materials }\end{array}$ & $\begin{array}{l}\text { 3. Sulitnya mencari tenaga kerja tetap/ } \\
\text { The difficulty of finding employment } \\
\text { remains }\end{array}$ \\
$\begin{array}{ll}\text { 4. Kurangnya pengetahuan tentang skema } \\
\text { dan mekanisme proyek secara utuh/ Lack } \\
\text { of knowledge about the schemes and } \\
\text { mechanisms of the project as a whole }\end{array}$ & $\begin{array}{l}\text { 4. Tinginya biaya operasional/ } \\
\text { High operational costs }\end{array}$ \\
$\begin{array}{l}\text { 5. Kurangnya pendampingan/lack of } \\
\text { assistance }\end{array}$ & \\
\hline
\end{tabular}

Sumber: Data Primer, 2014/ Source: Primary data, 2014

Pemberian bantuan freezer dalam program PUMP P2HP sangat berpengeruh positif terhadap posisi tawar pengolah. Sebelum memiliki freezer pengolah langsung menjual ikan olahannya setelah selesai proses pengolahan. namun saat ini mereka dapat menahan dulu penjualan ketika harga tidak menguntungkan.

Kegiatan diversifikasi olahan ikan seperti bakso ikan sudah mulai diperkenalkan Namun demikian, sampai survey dilakukan pemasaran bakso ikan tersebut masih terbatas pada skala rumah tangga. Kebiasaan makan ikan orang Aceh yang langsung dari ikan segar menyebabkan kesulitan menerima makanan olahan dari ikan.

\section{KESIMPULAN DAN IMPLIKASI KEBIJAKAN}

\section{Kesimpulan}

Kinerja input, proses dan output PUMP-P2HP berdasarkan dokumen administrasi yang diajukan, sudah sesuai dengan pedoman teknis yang ditetapkan oleh pemerintah pusat. Jika dilihat dari proses pelaksanaannya masih mengalami permasalahan dan kendala pada kriteria umum maupun khusus penerima PUMP-P2HP diantaranya mengenai identifikasi awal yang dilakukan oleh pendamping dan Dinas Kelautan dan Perikanan Kota Banda Aceh belum secara optimal, pendampingan kepada Poklahsar penerima bantuan tidak kontinyu hanya sampai pada bantuan tersalurkan, sebagian besar Poklahsar yang tidak melakukan usaha pengolahan dan pemasaran hasil perikanan sebatas menerima bantuan, Poklahsar tidak memiliki anggota baru yang merupakan tambahan tenaga kerja baru dan kepengurusan yang aktif hanya dilakukan oleh ketua Poklahsar.

Respon penerima bantuan terhadap pelaksanaan PUMP-P2HP tergolong dalam 3 (tiga) kategori yaitu kategori baik (penyaluran BLM dilakukan dengan lancar dan pemanfaatannya digunakan untuk pengembangan usaha), kategori sedang (tahapan penyaluran bantuan mulai dari identifikasi calon penerima hingga pelaporan perkembangan usaha) dan kategori rendah (penetapan kelompok calon penerima tidak dilakukan secara selektif dan ketat serta tidak adanya pendampingan, pembinaan dan pengendalian secara berkala).

Faktor pendukung PUMP-P2HP adalah ketepatan calon penerima bantuan, ketepatan pemilihan lokasi, jumlah alat olah, skala produksi dan status usaha, keterampilan usaha serta pengalaman usaha yang dimiliki oleh calon penerima BLM. Faktor penghambat keberhasilan pelaksanaan PUMP-P2HP yang dirasakan oleh penerima bantuan adalah belum adanya akses dan teknologi pengolahan sehingga pelaksanaan program PUMP-P2HP belum dapat dikatakan efektif. Pemberdayaan masyarakat kelautan dan perikanan yang sudah pernah ada belum mencapai sasaran bahkan ada yang gagal, dimana faktor kegagalan tersebut disebabkan permasalahan dalam pelaksanaannya. 
PUMP-P2HP dirasa belum memberikan dampak positif yang signifikan. Peningkatan produksi Poklahsar penerima bantuan belum maksimal karena masih banyak yang berproduksi hanya berdasarkan pesanan. Selain itu, penyerapan tenaga kerja belum terlihat karena usaha pengolahan belum terjadi peningkatan. Hal ini disebabkan oleh permasalahan utama yaitu terbatasnya akses pasar untuk memasarkan produk olahannya.

\section{Implikasi Kebijakan}

Program pemberdayaan masyarakat dalam bentuk bantuan langsung tunai yang akan ada di tahun-tahun mendatang, diharapkan kewenangan penetapan calon penerima bantuan harus didasarkan atas hasil verifikasi pelaksana di tingkat pusat bukan hanya kebijakan pemerintah daerah saja. Pemilihan prioritas penerima bantuan pengolahan dan pemasaran hasil perikanan berdasarkan klasifikasi kelompok yaitu bantuan teknologi dan informasi (untuk kelompok pemula), bantuan modal dan alat (untuk kelompok madya), fasilitasi untuk lembaga permodalan dan perbankan (untuk kelompok utama).

Program ini tidak selamanya dilaksanakan, oleh karena itu perlu dibangun pemikiran strategis mengenai exit strategy yang menjadi bagian yang tidak terpisahkan dalam pembangunan sektor kelautan dan perikanan di masa mendatang. Exit strategy yang dimaksud adalah pentahapan pengembangan KUKP yang kuat dan memiliki potensi untuk dikembangkan menjadi lembaga keuangan mikro dan berbadan hukum.

Penguatan peran pendampingan secara berkelanjutan juga diperlukan bukan hanya saat pelaksanaan program saja namun setelah selesai turun bantuan. Hal ini dapat dilakukan dengan membangun jaringan kerja secara lebih luas antara Dinas Kelautan dan Perikanan, Lembaga Penyuluhan dan Badan Pengembangan SDM Kelautan dan Perikanan. Selain itu juga perlu melakukan transformasi kelembagaan Poklahsar menjadi kelembagaan yang berbadan hukum.

Untuk mengatasi permasalahan pada usaha pengolahan hasil perikanan skala mikro khususnya untuk kelangsungan bahan baku dan rendahnya peluang pasar dapat dilakukan dengan cara peningkatan akses pasar produk olahan ikan melalui kemitraan atau kontrak kerja dengan pasar modern dan pengurusan ijin usaha; peningkatan kesadaran pengurusan ijin usaha, peningkatan fungsi kelembagaan Poklahsar untuk memfasilitasi perluasan akses pasar bagi anggota kelompok dan peningkatan kerjasama antara kelompok penerima dan non penerima melalui kemitraan.

\section{DAFTAR PUSTAKA}

Asih. D. N, Hariaanto dan N. Kusnadi. 2008. Dampak Kredit Terhadap Usaha Perikanan dan Ekonomi Rumah Tangga Nelayan Tradisional di Kabupaten Tojo Una-Una. Provinsi Sulawesi Tengah. Forum Pascasarjana. 31(4):269-278.

DJP2HP. 2013. Kelautan dan Perikanan dalam Angka. Pusat Data dan Informasi KKP. Jakarta

DJP2HP. 2013. Statistik Perikanan Tangkap di Laut Menurut WPP-RI 2005-2012. Direktorat Jenderal Perikanan Tangkap. KKP. Jakarta

DJP2HP. 2013. Pedoman Teknis Pengembangan Usaha Mina Pedesaan Pengolahan dan Pemasaran Hasil Perikanan Tahun 2013. Direktorat Jenderal Pengolahan dan Pemasaran Hasil Perikanan. KKP. Jakarta.

DJP2HP. 2011. Peta Keragaan Perikanan Tangkap Di Wilayah Pengelolaan Perikanan Republik Indonesia (WPP-RI). Direktorat Jenderal Perikanan Tangkap. KKP. Jakarta

Djalal, N. dan R. Lasabuda. 2012. Analisis Kinerja Stakeholder Program Nasional Pemberdayaan Masyarakat (PNPM)-Mandiri Kelautan dan Perikanan di Kota Ternate. Jurnal IImiah Platax, Vol. I No. 1 September 2012 : 24-28. Manado.

Dunn, N. 2003. Pengantar Analisis Kebijakan Publik.Gadjah Mada University Press. Yogyakarta.

Katiman. 2012. Pelaksanaan PNPM Mandiri dalam Upaya Penanggulangan Kemiskinan (Kasus PNPM Mandiri Pedesaan dan Perkotaan di Kecamatan Lohbener dan Kandanghaur, Kabupaten Indramayu, Propinsi Jawa Barat). Thesis. Universitas Gadjah Mada. Yogyakarta.

Moeloeng, L. J. 2006. Metodologi Penelitian Kualitatif. PT. Remaja Rosdakarya. Bandung.

Miles, M B. dan A. M. Huberman. 2007. Analisis Data Kualitatif: buku sumber tentang metode-metode baru. Diterjemahkan oleh: Tjetjep Rehendi Rohidi. UI-Press. Jakarta.. 
Muniza, M. 2010. Pengaruh Faktor-FaktorEksternal dan Internal Terhadap Kinerja Usaha Mikro dan Kecil (UMK) di Sulawesi Selatan. Jurnal Manajemen Dan Kewirausahaan.Vol: 12 (1): 33-41

Nikijuluw, V.P.H. 2001. Sosial Ekonomi Masyarakat Pesisir Dan Strategi Pemberdayaan Mereka dalam Konteks Pengelolaan Sumberdaya Pesisir Secara Terpadu. Prosiding Pelatihan Pengelolaan Wilayah Pesisir Terpadu. Bogor, 29 Oktober - 3 November 2001. Pusat Kajian Sumberdaya Pesisir dan Lautan Institut Pertanian Bogor. Bogor. 14-27

Paturohman, M. 2007. Hubungan Antara Pendapatan Dengan Tabungan (Kasus Pada Peternakan Sapi Perah Rakyat Pada Berbagai Skala Usaha Di KPBS). Fakultas Peternakan Universitas Padjadjaran. Bandung.
Sahuri, C., S. Achnes, D.Mashur dan Zulkarnaini. 2012. Pelaksanaan PNPM Mandiri dalam Peningkatan Kesejahteraan Masyarakat. Jurnal Kebijakan Publik Vol. 3 (2) : 59-141.

Samuelson, P.Adan W.D. Nordhaus. 1986. Ekonomi Edisi Keduabelas, Jili 1, Diterjemahkan oleh A. Jaka Wasana. Erlangga (157-167).

Shaw, I. F., J.C. Green and M. M. Mark. 2006. Hand Book of Evaluation. Sage Publication, Inc. London.

Sugiyono. 2010. Metode Penelitian Kualitatif, Kuntitatif dan R\&D. Cetakan Kesebelas. Alfabeta. Bandung. Hal. 13-33.

Yulianti, D. 2012. Efektivitas Program PTPN 7 Peduli di PTPN VII (Persero) Lampung (suatu evaluasi atas program SCR). Jurnal IlmiahAdministrasi Publik dan Pembangunan 3 (1): 408-420. 